\title{
CHARACTERISTICS OF NOVEL POLYMER BASED ON PSEUDO-POLYAMINO ACIDS GluLa-DPG-PEG600: BINDING OF ALBUMIN, BIOCOMPATIBILITY, BIODISTRIBUTION AND POTENTIAL CROSSING THE BLOOD-BRAIN BARRIER IN RATS
}

\author{
B. O. CHEKH $H^{1}$, M. V. FERENS ${ }^{2}$, D. D. OSTAPIV ${ }^{1}$, V. Y. SAMARYK ${ }^{2}$, \\ S. M. VARVARENKO ${ }^{2}, V$. V. VLIZLO ${ }^{1}$ \\ ${ }^{1}$ Institute of Animal Biology, NAAS of Ukraine, Lviv; \\ ${ }^{2}$ National University "Lviv Polytechnic", Ukraine; \\ e-mail: bogdanchekh@gmail.com
}

The aim of our work was to study biological properties of the polymer based on pseudo-polyamino acids GluLa-DPG-PEG600, its ability to bind albumin, as well as its localization in rat body and influence on physiological and functional state of rat kidneys and liver. We have found the ability of GluLa-DPG-PEG600 to bind bovine serum albumin (BSA) using electrophoresis in 5\% polyacrylamide gel. Structural and functional state of the liver and kidneys of rats after injections of polymer were investigated by histological analysis of organs and determination the activities of alanine aminotransferase, aspartate aminotransferase, alkaline phosphatase, gamma-glutamyltransferase and content of cholesterol and creatinine in blood. Our results showed little toxic effect of GluLa-DPG-PEG600 on rat body. Using fluorescent microscopy we have studied polymer in complex with BSA distribution in rat body: after intravenous injection polymer are localized in kidneys and spleen, and after intramuscular - in liver and brain. It has been shown that polymer passed through the blood-brain barrier and are localized in the immune organ - spleen, indicating GluLa-DPG-PEG600 as a potential drug transporter.

Key words: polymer based on pseudo-polyamino acids, drug transporter, adjuvant, liver and kidneys of rats.

$\mathrm{N}$ owadays, one of the main task for pharmacy is development a novel polymeric compounds for drug delivery and other biomedical purposes [1]. It has been developed polymers based on amino acids with good biocompatibility like hydrogel based on poly $\gamma$-glutamic acid ( $\gamma$-PGA) and $\varepsilon$-polylysine ( $\varepsilon$-PL) or able to adsorb rare earth elements like sodium alginate hydrogel linked with poly- $\gamma$-glutamate $[2,3]$. Scientists also developed specific polymers for drug delivery, for example lysine-based hydrogels for the oral delivery which are $\mathrm{pH}$-sensitive or safe detoxifying agent like $\operatorname{poly}(\gamma$-glutamic acid) $[4,5]$. We develop and research polymers based on pseudo-polyamino acids which, like polymers based on amino acids, have good biocompatibility but are more stable for degradation.

Pseudo-polyamino acids - class of polymeric compounds based on natural amino acids. Their structure doesn't contain peptide bonds, ones can be changed to urethane, ester, anhydrite and other chemical bonds [6]. Drug delivery systems based on pseudo-polyamino acids with ester bonds are respectable for research and developing. Pseudo-polyamino acids based on glycine, asparagine, arginine and lysine in complex with lactic acid are biodegradable and have advanced cell adhesion [7-9]. Pseudo-polyamino acids based on tyrosine in complexes with $\mathrm{ZnO}$ can be used in anticancer therapy [10, 11]. The main advantages of this class of polymers as drug transporters are their biodegradability and prolonged time of degradation that correlates with releasing of drugs active components (for example, polymers based on glycine and lactic acid are decomposed for about 10 weeks) [7, 8]. Polymer GluLa-DPG-PEG600 based on glutamic acid with ester bonds was developed. Therefore, the main purpose

(C) 2017 Chekh B. O. et al. This is an open-access article distributed under the terms of the Creative Commons Attribution License, which permits unrestricted use, distribution, and reproduction in any medium, provided the original author and source are credited. 
of our study was to research polymer as drug transporter particularly its ability to bind serum blood proteins, influence on rats and polymer distribution in their body.

\section{Matherials and Methods}

For this study we synthesized polymer GluLaDPG-PEG600 which consist of glutamic and lauric acids (GluLa), dipropylene glycol (DPG), and polyethylene glycol 600 (PEG600). Fluorescein (F) was covalently attached to polymer GluLa-DPG-PEG600 to study their distribution in rat body (Fig. 1.). Polymers were synthesized accordingly to methods $[12,13]$.

For assessment of the ability of GluLa-DPGPEG600 to bind serum blood proteins we tested $2 \%$ water dispersion of GluLa-DPG-PEG600 and the same dispersion with $1 \%$ water solution of BSA (molecular weight $=66 \mathrm{kDa}$ ) was tested by electrophoresis in 5\% polyacrylamide gel [14].

GluLa-DPG-PEG600 influence on rat body were investigated by the analysis of histological structure of liver and kidneys. We also determined the activities of key indicators enzymes of liver and kidneys functional state - alanine aminotransferase (ALT), aspartate aminotransferase (AST), alkaline phosphatase (ALP), $\gamma$-glutamyltransferase (GGT) and content of cholesterol and creatinine in blood. The animals were divided into 4 experimental groups of male aged 6 months Rattus norvegicus var. alba. Each group consisted of 9 rats and weight of 1 animal was approximately 250-300 g maintained under standard laboratory conditions. On the $1^{\text {st }}$, $7^{\text {th }}$ and $14^{\text {th }}$ days of experiment, rats from first experimental group were intramuscularly injected by saline. In the same way, animals from second experimental group were intramuscularly injected by $0.3 \mathrm{ml}$ 1\% GluLa-DPG-PEG600, from third group -
$0.3 \mathrm{ml}$ 1\% GluLa-DPG-PEG600 with $0.3 \mathrm{ml} \mathrm{1 \%} \mathrm{BSA}$ and fourth group $-0.3 \mathrm{ml} 1 \%$ BSA. On the $7^{\text {th }}, 14^{\text {th }}$ and $21^{\text {st }}$ days of experiment - rats from every experimental group were anesthetized with chloroform and decapitated. Activities of alanine aminotransferase (ALT, EC 2.6.1.2), aspartate aminotransferase (AST, EC 2.6.1.1), alkaline phosphatase (ALP, EC 3.1.3.1), $\gamma$-glutamyl transferase (GGT, EC 2.3.2.2) and content of cholesterol and creatinine were determined in rat blood serum using biochemical analyser $\mathrm{Hu}-$ maLyzer 2000 (Human $\AA$ ). Histological structure of liver and kidneys were investigated in accordance with methods [14].

Polymer distribution in rat body was studied by fluorescent microscopy. Complex of $2 \%$ water dispersion of GluLa-DPG-PEG600-F with $1 \%$ water solution of BSA was labeled with Alexa Fluor 555 fluorescent dye (ThermoFisher $\left.{ }^{\circledR}\right)$ in ratio of 2.5:1 and maintained at $18{ }^{\circ} \mathrm{C}$ for $1 \mathrm{~h}$. For this purpose 2 experimental groups and 1 control group of Rattus norvegicus var. alba line Wistar, consisted of 3 rats and weight of 1 animal was approximately 250$300 \mathrm{~g}$ were formed. Rats from control group were intact. Rats from first experimental group were intravenously injected by $0.3 \mathrm{ml}$ of water dispertion of GluLa-DPG-PEG600-F + BSA Alexa Fluor 555 complexes and euthanized at soft chloroform condition in $5 \mathrm{~h}$ after the injections. Second experimental group of rats were intramuscularly injected by $0.3 \mathrm{ml}$ of water dispertion of GluLa-DPG-PEG600-F + BSA Alexa Fluor 555 complexes and euthanized at soft chloroform condition in $16 \mathrm{~h}$ after the injections. Histological analysis of spleen, liver, brain and kidneys was conducted by cryostat. Fluorescence of GluLa-DPG-PEG600-F + BSA Alexa Fluor 555 complexes with $656 \mathrm{~nm}$ wavelength via Leica DM2500® microscope and Leica Application Suite ${ }^{\circledR}$ software was observed. Statistical processing

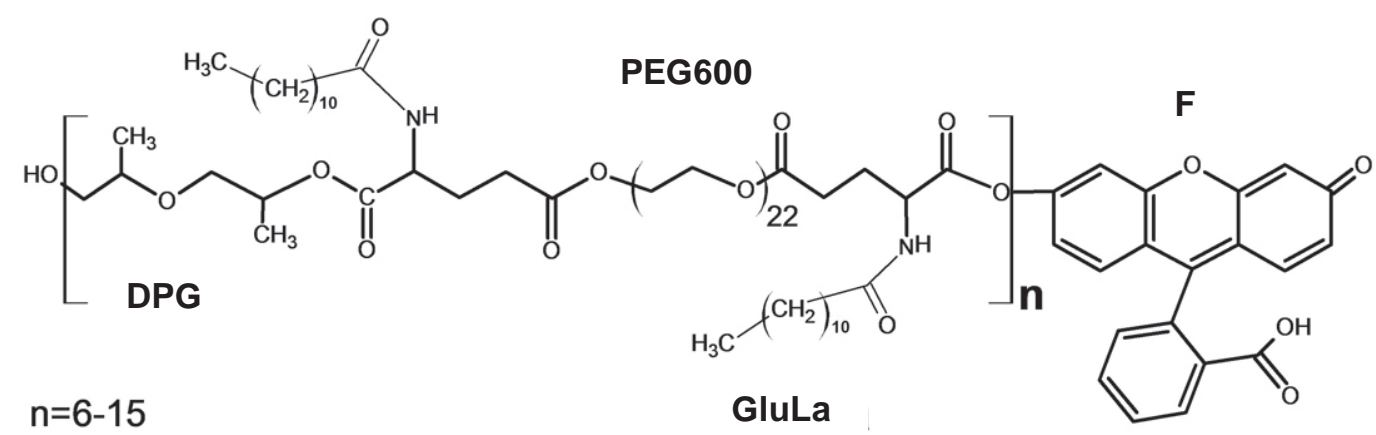

Fig. 1. Structure of GluLa-DPG-PEG600-F 
of the investigation results was made using the pack of Microsoft Excel programs.

All experiments were performed in accordance with the Ministry of Education and Science of Ukraine, order No 281 from 01.11.2000, the European Convention for Protection of Vertebrate Animals Used for Experimental and Other Scientific Purposes (18.03.1986), EU Directive No 609 (24.11.1986).

\section{Results and Discussion}

The ability of GluLa-DPG-PEG600 to bind BSA was studied using electrophoresis in 5\% polyacrylamide gel (Fig. 2). Serum albumins are the main transporters for xenobiotics and nutrients in blood. The ability to bind BSA is a positive characteristic of synthesized polymers, as a drug transporter. For example similar polymers - esters of microbial $\operatorname{poly}(\gamma$-glutamic acid) can encapsulate erythromycin and $\alpha$-chymotrypsin [15]. It has been shown the ability of poly( $\gamma$-glutamic acid) to sorb albumin molecules [16].

For assessment of the influence of GluLa-DPGPEG600 on rat body, the structure and functional state of kidneys and liver were studied.

We have been found that on the $7^{\text {th }}$ day on experiment, rats from $1^{\text {st }}$ experimental group had increased with significant values $P<0.05$, AST activity by $28 \%,(P<0.01)$ ALT activity by $55 \%$, $(P<0.05)$ ALP - on $13 \%$ and creatinine content by $29 \%$ compared with control group animals. Rats from $2^{\text {nd }}$ experimental group had increased $(P<0.05)$ AST activity by $26 \%,(P<0.01)$ ALT by $47 \%,(P<0.05)$ GGT - by $34 \%$ and creatinine content - by $30 \% .3^{\text {rd }}$ experimental group of animals had unchanged enzymes activities, and creatinine content which were the same as in the control group of animals. Level of cholesterol was in the range of physiological fluctuations in rats from all experimental groups.

According to obtained results - increased activities of AST and ALT are the indicators of the functional state of hepatocytes and may attest the defections of hepatocytes structure. The increased activity of GGT may be a sign of the distraction of the cells that forms intrahepatic bile ducts, while ALP - destruction of the cells that forms extrahepatic bile ducts on ultramicroscopic level. Increased level of creatinine in rats blood of the $1^{\text {st }}$ and $2^{\text {nd }}$ experimental groups compared with the control group of animals, may indicate the decreased glomerular filtration rate.

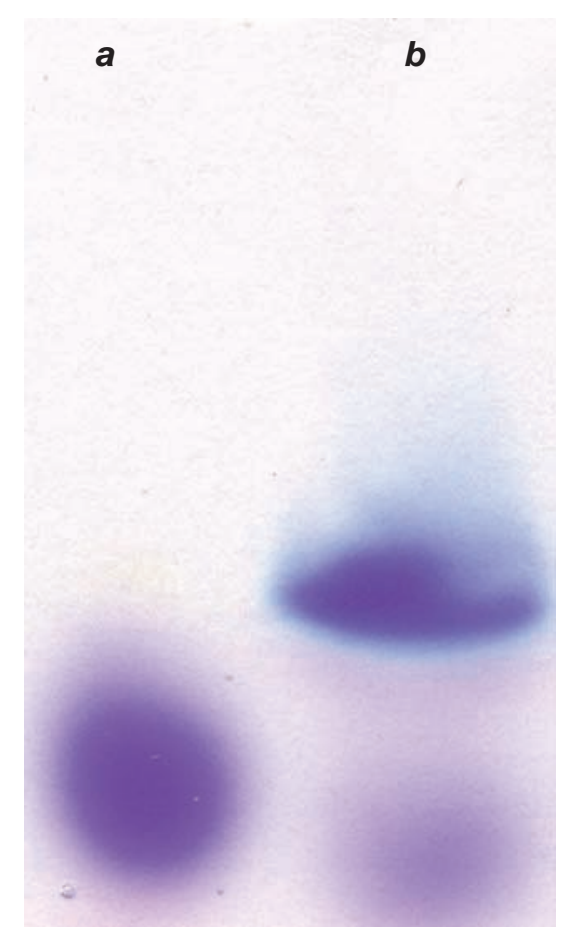

Fig. 2. Electrophoresis in 5\% polyacrylamide gel: $a-B S A, b-B S A$ with GluLa-DPG-PEG600

Using histological analysis we have been found few sites of inflammation in ascending convoluted tubules of nephrons in animals from the $1^{\text {st }}$ and $2^{\text {nd }}$ experimental groups on the $7^{\text {th }}$ and $14^{\text {th }}$ days of the experiment, that accompanied by changes in enzyme activities (Fig. 5).

Increased activity of AST by $20 \%(P<0.05)$ in rats blood from the $1^{\text {st }}$ experimental and by $25 \%$ $(P<0.05)$ in animals from the $2^{\text {nd }}$ group were detected on the $14^{\text {th }}$ day of the experiment. We also detected increased ALT activity by $27 \%(P<0.05)$ and $33 \%(P<0.05)$ in rats from the $1^{\text {st }}$ and $2^{\text {nd }}$ experimental groups, while activities of AST and ALT in rats blood from the $3^{\text {rd }}$ group were the same as in control group. Activities of ALP, GGT, creatinine and cholesterol content in animals of all experimental groups were the same as in the control group. However, inflammation in ascending convoluted tubules of nephrons were detected in rats from the $2^{\text {nd }}$ experimental group that can be the result of decreased glomerular filtration rate.

It has been found, that on the $21^{\text {st }}$ day - level of activities of ALT AST ALP GGT and content of creatinine and cholesterol in all groups of animals were in the range of physiological fluctuations. Investigation of rats liver and kidneys histological structure 

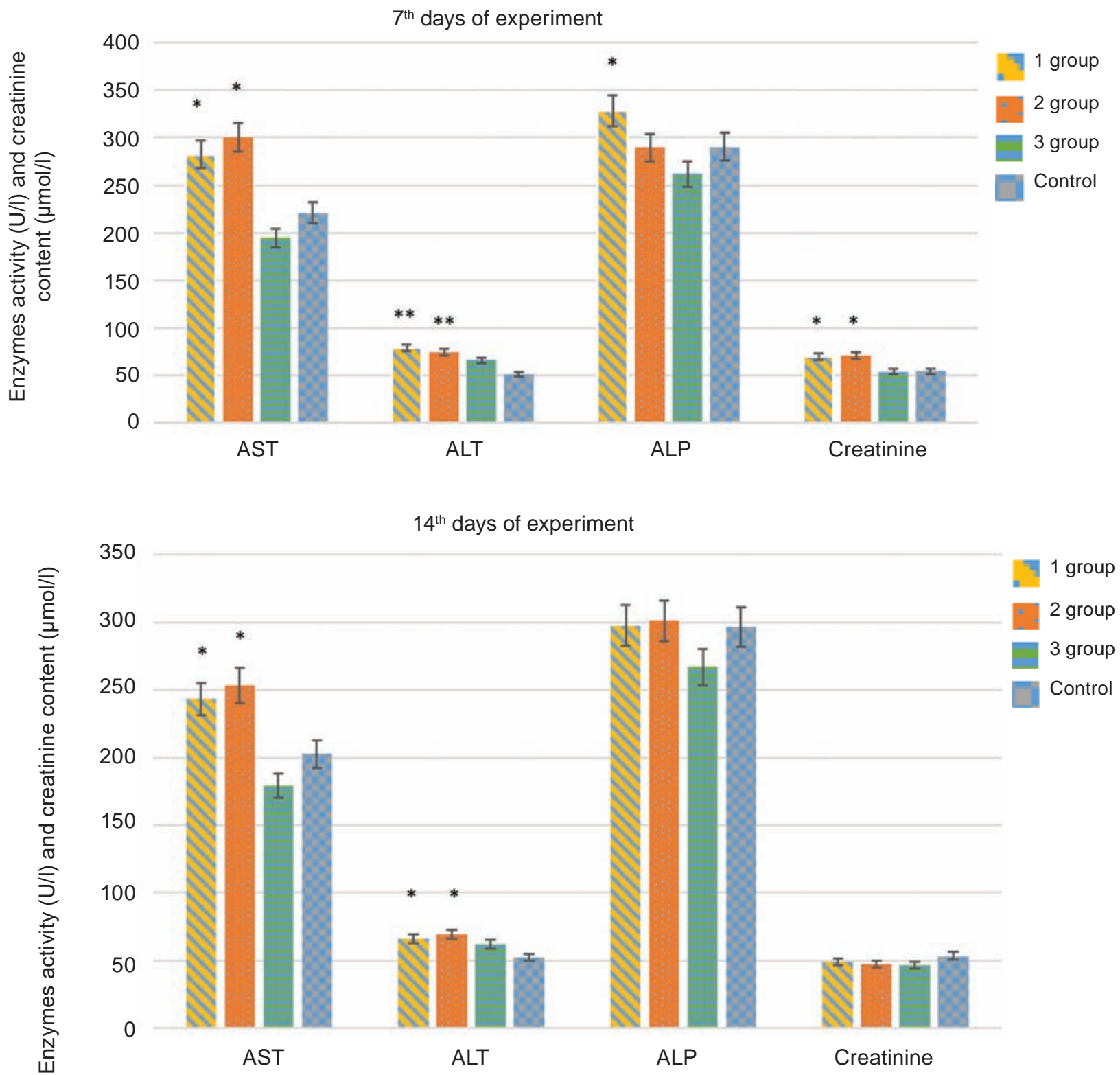

Fig. 3. AST, ALT, ALP activities and creatinine content on the $7^{\text {th }}, 14^{\text {th }}$ days of experiment in control and experimental groups of animals; $n=3, M \pm m,{ }^{*} P<0.05$, ${ }^{* *} P<0.01$

revealed that on the $21^{\text {st }}$ day of experiment - structure of organs from all experimental groups were without pathological changes. Using histological analysis we detected no changes of liver structure during the experiment.

The absence of the negative impact of GluLaDPG-PEG600 on the $21^{\text {st }}$ day of the experiment shows that polymer has temporary toxic effect on rat body. The fact, that on the $14^{\text {th }}$ and $21^{\text {st }}$ days of experiments after two and three polymer injections toxic effect was reduced that may indicate adaptation processes in rat body. The non-toxicity and biocom- patibility of this class of polymers are confirmed by several studies [17]. In addition, amino acid-based polymers, such as polyglutamic acid, polyaspartic acid are widely used in biomedical application due to their biocompatibility, enhanced solubility and low profile cytotoxicity [18].

Polymer distribution in rat body was investigated by fluorescent microscopy using fluorescein labeled polymer GluLa-DPG-PEG600-F in complex with BSA labeled Alexa Fluor 555 dye. Obtained results showed that polymer with BSA in $5 \mathrm{~h}$ after intravenous injection were localized in rat kidneys and 


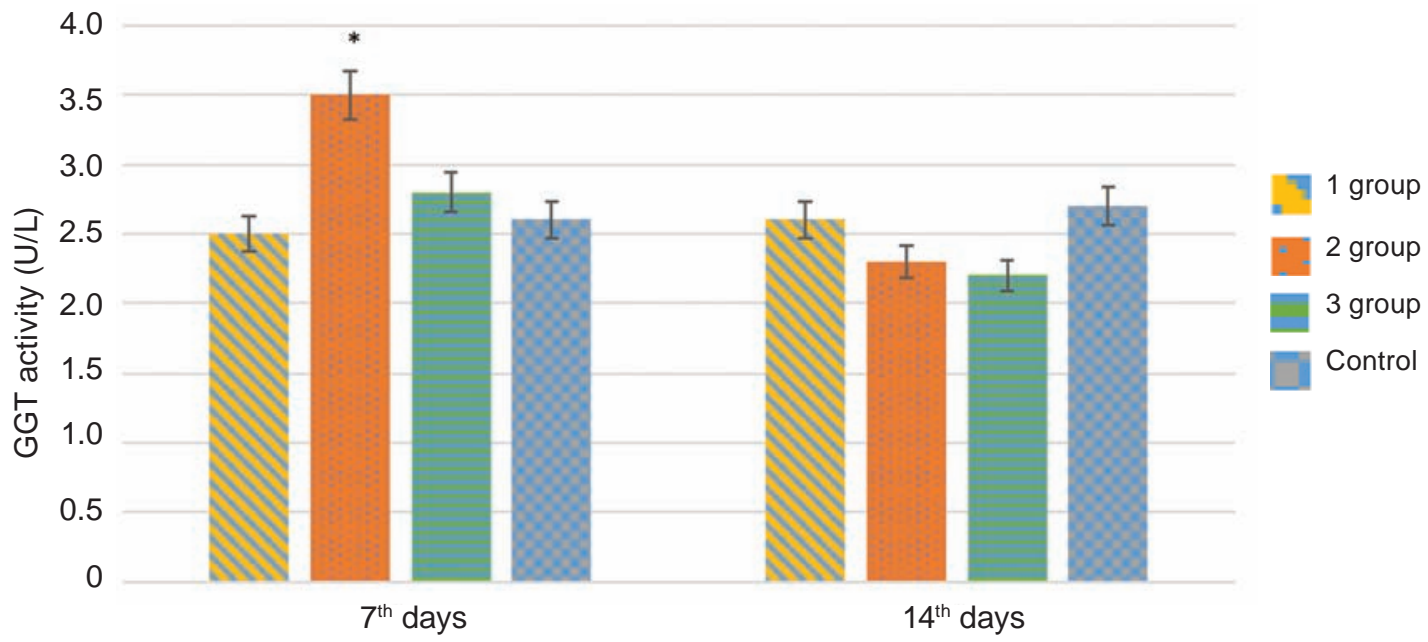

Fig. 4. GGT activity on the $7^{\text {th }}, 14^{\text {th }}$ days of experiment in control and experimental groups of animals; $n=3$, $M \pm m, * P<0.05$
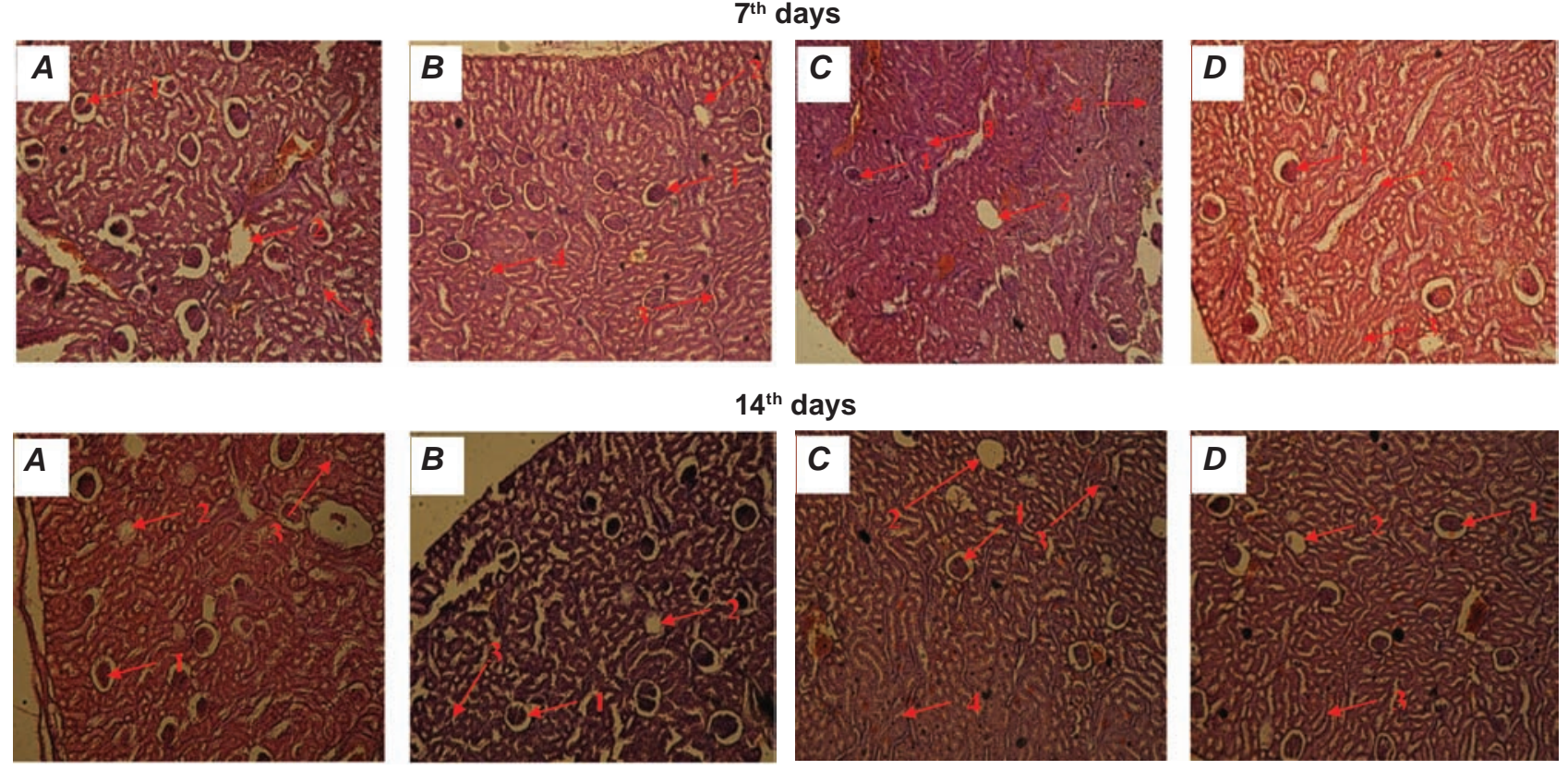

Fig. 5. Microstructure of kidneys on the $7^{\text {th }}$ and $14^{\text {th }}$ days of experiment; hematoxylin and eosin staining of tissue (total magnification $-100 x$ ): $\boldsymbol{A}$ - control, $\boldsymbol{B}-1^{\text {st }}$ experimental group, $\boldsymbol{C}-2^{\text {nd }}$ experimental group, $\boldsymbol{D}-$ $3^{\text {rd }}$ experimental group, 1 - renal corpuscles, 2 - vessel wall, 3 - ascending convoluted tubules of nephrons, 4 - site of inflammation process in ascending convoluted tubules of nephrons

spleen (Fig. 6). In kidneys complexes were localized in the cortical layer and in the lumens of veins in a zone of proximal convoluted tubules. In the control group of rats, structures with the same luminescence were not detected (Fig. 6). Detection of polymer with BSA complexes in kidneys indicates that they are excreted by the kidney.

Detection of GluLa-DPG-PEG600-F with BSA complexes in rat spleen is a positive charac- teristic of polymer as a potential adjuvant for vaccine development, because lymphocytes and antigen dependent antibody differentiation processes take place in spleen and this immune organ can provide quick and effective immune response to vaccine antigens. For example, other studies showed, that poly $(\gamma$-glutamic acid) nano-particles combined with mucosal influenza virus hemagglutinin vaccine protects against influenza virus infection in mice and may 

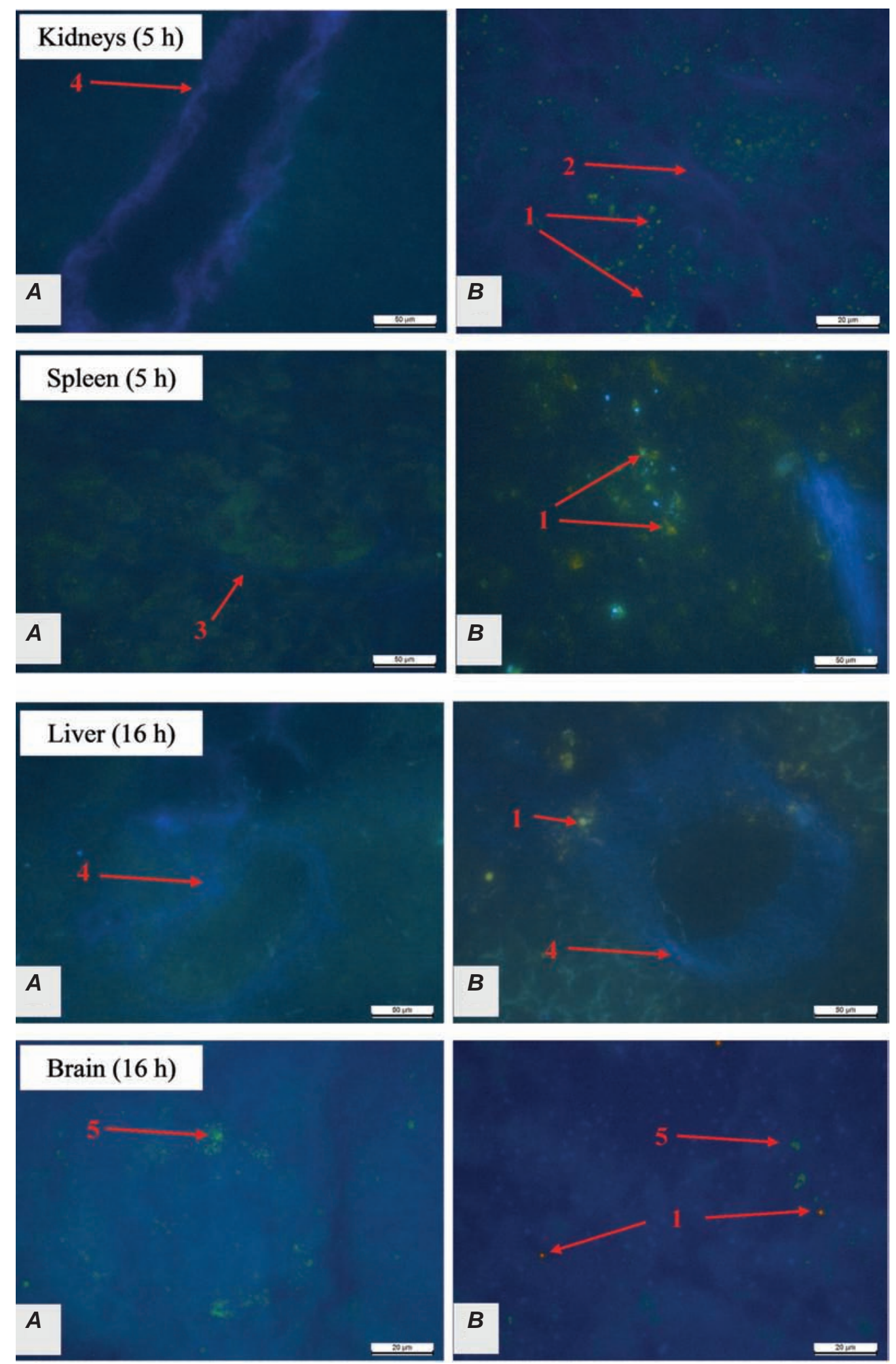

Fig. 6. Localization of GluLa-DPG-PEG600-F + BSA Alexa Fluor 555 complexes in rat kidneys and spleen in $5 \mathrm{~h}$ after intramuscular injections and in liver and brain in $16 \mathrm{~h}$ after intravenous injections: $\boldsymbol{A}$ - control group of rats, $\boldsymbol{B}$ - experimental group of rats (total magnification $=900 x$ ), 1 - luminescence of GluLa-DPGPEG600-F with BSA Alexa Fluor, 2 - vein in a zone of proximal convoluted tubules, 3 - lymph node, 4 - liver blood vessel wall, 5 - luminescence of catecholamines 
have potential for clinical applications as a mucosal adjuvant [19].

We found the localization of GluLa-DPGPEG600-F + BSA Alexa Fluor 555 complexes in $16 \mathrm{~h}$ after intramuscular injections in rat brain and liver. Complexes were detected in liver lobules near hepatic vessels and inside it. In liver from control group of rats structures with the same fluorescence were absent (Fig. 6).

Luminescence of these complexes were detected in brain tissue in $16 \mathrm{~h}$ after intramuscular injections. In control group and experimental group of animals in brain tissues were detected luminescence of catecholamines (Fig. 6). Detection of GluLaDPG-PEG600-F + BSA Alexa Fluor 555 complexes in brain indicates its ability to penetrate the bloodbrain barrier. Earlier, it has been shown that this class of polymers in complexes with albumins is able to form rod-shaped particles with a hydrodynamic diameter of 40-70 $\mathrm{nm}$ which can penetrate the bloodbrain barrier. That is because BSA molecules were adsorbed on the surface of GluLa-DPG-PEG600-F and acted as an additional stabilizer of a dispersed phase of the polymer which reduces the linear sizes of the particles by fragmentation of large particles into smaller [20].

In conclusions it has been found that polymer GluLa-DPG-PEG600 can bind bovine serum albumin that suggests its possible using as a potential transporter for proteins and their complexes. GluLa-DPG-PEG600 characterized by little short-term toxic effect on rat body, evidenced by increased activities of studied enzymes and minor pathological changes in kidneys structure. Obtained results demonstrate that polymer is safe for rat body and applicable for further research as a drug transporter.

Analysis of polymer distribution in rat body revealed that polymer GluLa-DPG-PEG600 in complexes with BSA are localized in rat kidney and spleen after intravenous injections that indicates that these complexes are excreted by the kidneys. This feature demonstrates the polymer as a potential adjuvant for vaccine development. Polymer localization in liver and brain tissues after intramuscular injections indicates that polymer can penetrate bloodbrain barrier. There are important features of the polymer as a potential drug transporter.

In further studies we will determine the ability of GluLa-DPG-PEG600 to transport drugs as vaccines antigens and antibiotics, and the influence of these compounds on animals.

\section{ХАРАКТЕРИСТИКИ НОВОГО \\ ПОЛІМЕРУ НА ОСНОВІ \\ ПСЕВДОПОЛІАМІНОКИСЛОТ \\ GluLa-DPG-PEG600: ЗВ’ЯЗУВАННЯ \\ АЛЬБУМІНУ, БІОСУ МІСНІСТЬ, БІОРОЗПОВСЮДЖЕННЯ ТА ПОТЕНЦІЙНА ЗДАТНІСТЬ ПРОХОДИТИ КРІЗЬ ГЕМАТОЕНЦЕФАЛІЧНИЙ БАР'ЄР У ЩУРІВ}
Б. О. Чех ${ }^{1}$, М. В. Ференс ${ }^{2}$, Д. Д. Ocmanis ${ }^{1}$, В. Я. Самарик², С. М. Варваренко ${ }^{2}$, B. В. Влізло

${ }^{1}$ Інститут біології тварин НААН, Львів, Україна; ${ }^{2}$ Національний університет «Львівська політехніка», Україна; e-mail: bogdanchekh@gmail.com

Мета роботи дослідити біологічну властивість полімеру, синтезованого на основі GluLa-DPG-PEG600, зокрема здатність цього полімеру зв'язувати альбумін, його локалізацію в організмі та вплив на структурний і функціональний стан печінки і нирок щурів. За допомогою електрофорезу в 5\%му поліакриламідному гелі встановлено, що полімер GluLa-DPG-PEG600 здатний зв'язувати бичачий сироватковий альбумін (БСА). Дослідження структурного і функціонального стану печінки та нирок щурів виявили незначний токсичний вплив полімеру на організм щурів зі здатністю організму до адаптації. За допомогою люмінесцентної мікроскопії показано, що полімер у комплексі з БСА за внутрішньом'язового введення локалізувався в печінці та мозку, а внутрішньовенного - в нирках та селезінці щурів. Це, зокрема, є показником здатності полімеру проходити крізь гематоенцефалічний бар'єр та локалізуватись у селезінці, яка є імунним органом, що свідчить про можливе використання GluLa-DPG-PEG600 як потенційного транспортера лікарських засобів.

Кл юч ов і слова: полімер на основі псевдополіамінокислот, транспортер лікарських засобів, ад’ювант, печінка та нирки щурів. 


\section{ХАРАКТЕРИСТИКИ НОВОГО \\ ПОЛИМЕРА НА ОСНОВЕ \\ ПСЕВДОПОЛИАМИНОКИСЛОТ \\ GluLa-DPG-PEG600: \\ СВЯЗЫВАНИЕ АЛЬБУМИНА, БИОСОВМЕСТИМОСТЬ, БИОРАСПРОСТРАНЕНИЕ \\ И ПОТЕНЦИАЛЬНАЯ \\ ВОЗМОЖНОСТЬ \\ ПРОХОДИТЬ ЧЕРЕЗ \\ ГЕМАТОЭНЦЕФАЛИЧЕСКИЙ \\ БАРЬЕР У КРЫС}

Б. А. Чех ${ }^{1}$, М. В. Ференс ${ }^{2}$ Д. Д. Остапив ${ }^{1}$,

В. Я. Самарик , С. М. Варваренко ${ }^{2}$,

В. В. Влизло ${ }^{1}$

${ }^{1}$ Институт биологии животных НААН, Львов, Украина;

${ }^{2}$ Национальный университет «Львовская политехника», Украина;

e-mail: bogdanchekh@gmail.com

Цель работы - исследовать биологические свойства полимера, синтезированного на основе GluLa-DPG-PEG600, в частности способность этого полимера связывать альбумин, его локализацию в организме и влияние на структурное и функциональное состояние печени и почек крыс. С помощью электрофореза в 5\%-ом полиакриламидном геле установлено, что полимер GluLa-DPG-PEG600 способен связывать бычий сывороточный альбумин (БСА). При изучении структурного и функционального состояния печени и почек крыс обнаружено незначительное токсическое воздействие полимера на организм крыс со способностью организма к адаптации. $\mathrm{C}$ помощью люминесцентной микроскопии показано, что полимер в комплексе с БСА при внутримышечном введении локализовался в печени и мозге, а при внутривенном - в почках и селезенке крыс. Это, в частности, является показателем способности полимера проходить через гематоэнцефалический барьер и локализоваться в селезенке - иммунном органе, что свидетельствует о возможном использовании GluLa-DPGPEG600 в качестве потенциального транспортера лекарственных средств.

К л ю ч в ы е с ло в а: полимер на основе псевдополиаминокислот, транспортер лекарственных средств, адъювант, печень и почки крыс.

\section{References}

1. Hubbell JA. Bioactive biomaterials. Curr Opin Biotechnol. 1999; 10(2): 123-129.

2. Hua J, Li Z, Xia W, Yang N, Gong J, Zhang J, Qiao C. Preparation and properties of EDC/NHS mediated crosslinking poly (gamma-glutamic acid)/epsilon-polylysine hydrogels. Mater Sci Eng C Mater Biol Appl. 2016; 61: 879-892.

3. Xu S, Wang Z, Gao Y, Zhang S, Wu K. Adsorption of Rare Earths(III) Using an Efficient Sodium Alginate Hydrogel Cross-Linked with Poly- $\gamma$ Glutamate. PLoS One. 2015; 10(5): e0124826.

4. Watkins KA, Chen R. pH-responsive, lysinebased hydrogels for the oral delivery of a wide size range of molecules. Int J Pharm. 2015; 478(2): 496-503.

5. Rajan YC, Inbaraj BS, Chen BH. In vitro adsorption of aluminum by an edible biopolymer poly(y-glutamic acid). J Agric Food Chem. 2014; 62(20): 4803-4811.

6. Lee KY, Mooney DJ. Hydrogels for tissue engineering. Chem Rev. 2001; 101(7): 1869-1879.

7. Arakelova E, Khachatryan A, Avjyan K, Farmazyan Z, Mirzoyan A., Savchenko L, Ghazaryan S, Arsenyan F. Zinc oxide nanocomposites with antitumor activity. Nat Sci. 2010; 2(12): 1341-1348.

8. Barrera DA, Zylstra E, Lansbury PT, Langer R. Synthesis and RGD peptide modification of a new biodegradable copolymer: poly(lactide acid-co-lysine). J Am Chem Soc. 1993; 115(23): 11010-11011.

9. Schakenraad JM, Dijkstra PJ. Biocompatibility of poly (DL-lactic acid/glycine) copolymers. Clin Mater. 1991; 7(3): 253-269.

10. Díaz A, Katsarava R, Puiggalí J. Synthesis, properties and applications of biodegradable polymers derived from diols and dicarboxylic acids: from polyesters to poly(ester amide)s. Int J Mol Sci. 2014; 15(5): 7064-7123.

11. Sarkar D, Yang JC, Gupta AS, Lopina ST. Synthesis and characterization of L-tyrosine based polyurethanes for biomaterial applications. J Biomed Mater Res A. 2009; 90(1): 263-271.

12. Varvarenko SM, Nosova NG, Dron IA, Voronov AS, Fihurka NV, Tarnavchyk IT, Taras RS, Vostres VB, Samaryk VY, Voronov SA. Novel amino-functional amphiphilic polyesters and dispersed systems based on them. Issues Chemistry Chem Technol. 2013; 5: 27-32. (In Ukrainian). 
13. Varvarenko SM, Samaryk V. Y., Vlizlo VV, Ostapiv DD, Nosova NG, Tarnavchyk IT, Fihurka NV, Ferens MV, Nagornyak MI, Taras RS, Yaremchuk IM, Voronov AS, Voronov SA. Fluorescein-containing theranostics based on the pseudo-poly(amino acid)s for monitoring of drug delivery and release. Polymer J. 2015; 37(2): 193-199. (In Ukrainian).

14. Vlizlo VV, Fedoruk RS, Ratych IB. Laboratory methods of research in biology, stockbreeding and veterinary medicine. Lviv: SPOLOM, 2012. 764 p. (In Ukrainian).

15. Portilla-Arias JA, Camargo B, GarcíaAlvarez M, de Ilarduya AM, Muñoz-Guerra S. Nanoparticles made of microbial poly(gammaglutamate)s for encapsulation and delivery of drugs and proteins. J Biomater Sci Polym Ed. 2009; 20(7-8): 1065-1079.

16. Yang JM, Tsai RZ, Hsu CC. Protein adsorption on polyanion/polycation layer-by-layer assembled polyelectrolyte films. Colloids Surf B Biointerfaces. 2016; 142: 98-104.
17. Ulery BD, Nair LS, Laurencin CT. Biomedical Applications of Biodegradable Polymers. $J$ Polym Sci B Polym Phys. 2011; 49(12): 832-864.

18. Santra S, Perez JM. Selective N-alkylation of $\beta$-alanine facilitates the synthesis of a poly(amino acid)-based theranostic nanoagent. Biomacromolecules. 2011; 12(11): 3917-3927.

19. Okamoto S, Matsuura M, Akagi T, Akashi M, Tanimoto T, Ishikawa T, Takahashi M, Yamanishi K, Mori Y. Poly(gamma-glutamic acid) nano-particles combined with mucosal influenza virus hemagglutinin vaccine protects against influenza virus infection in mice. Vaccine. 2009; 27(42): 5896-5905.

20. Varvarenko S, Tarnavchyk I, Voronov A, Fihurka N, Dron I, NNosova N, Taras R, Samaryk V, Vorono S. Synthesis and colloidal properties of polyesters based on glutamic acids and glycols of different nature. Chem Chem Technol. 2013; 7(2): 164-168.

Received 28.03.2017 